\title{
Forest conservation in Nepal: Encouraging women's participation
}

Augusta Molnar

Follow this and additional works at: https://knowledgecommons.popcouncil.org/departments_sbsr-pgy

Part of the Environmental Health and Protection Commons, Family, Life Course, and Society

Commons, Forest Sciences Commons, Gender and Sexuality Commons, International Public Health

Commons, Natural Resources and Conservation Commons, Place and Environment Commons, and the Sustainability Commons

How does access to this work benefit you? Let us know!

\section{Recommended Citation}

Molnar, Augusta. 1987. "Forest conservation in Nepal: Encouraging women's participation," SEEDS no. 10. New York: Population Council. 


\section{1)}

.

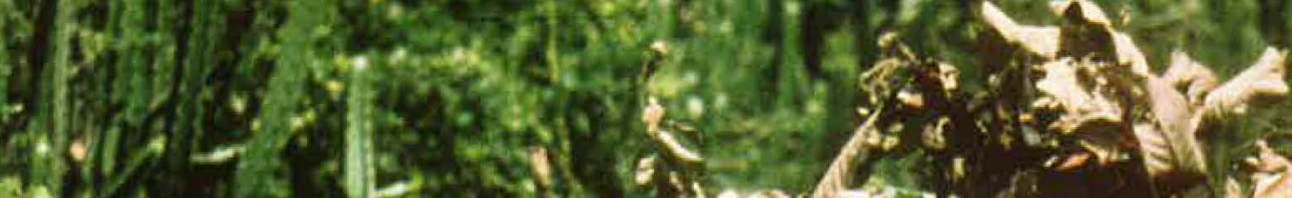

$x^{2}+x^{2}=x^{2}$

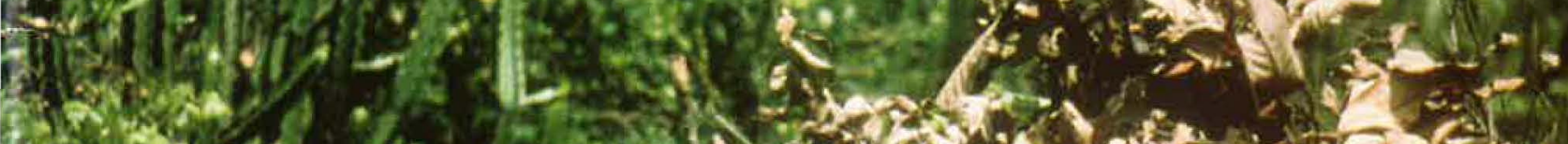

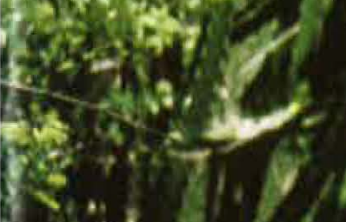

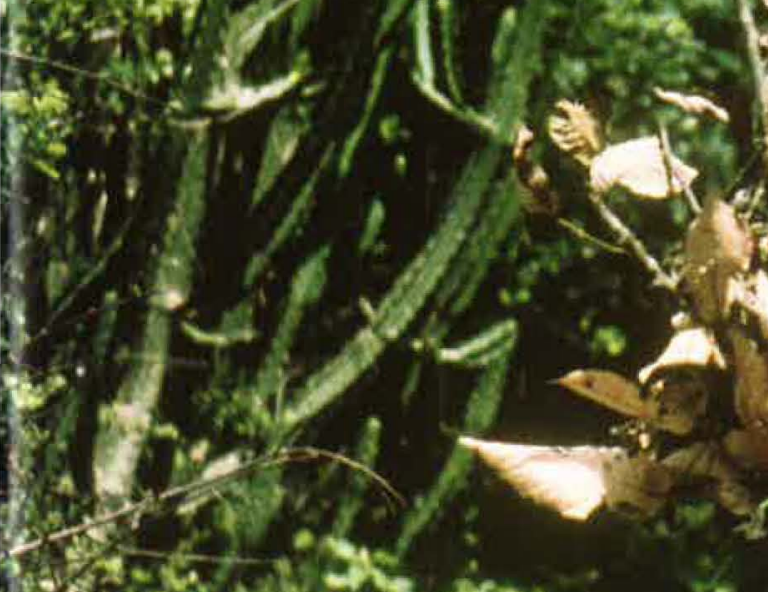
$\sec 2(2)=$

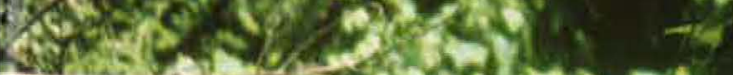
a s. Dons.

i. 20 2.

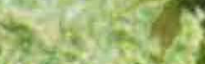
.

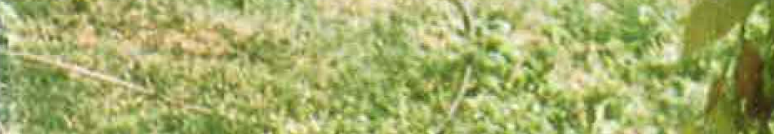

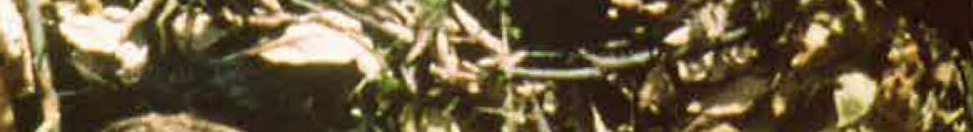

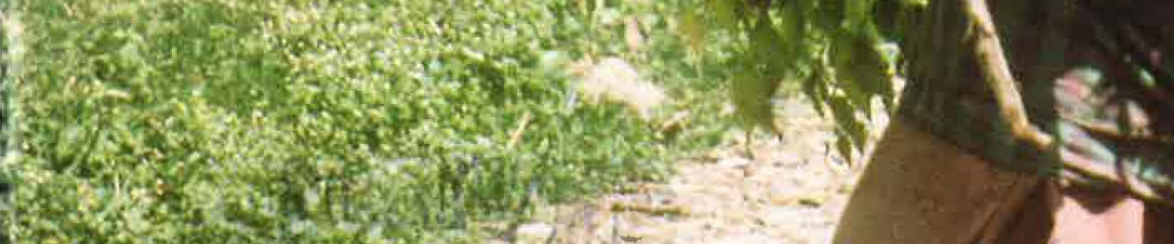

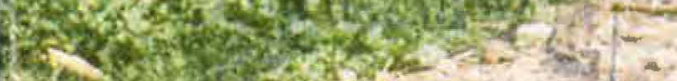

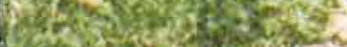
20.

HQ

1870.9

$+4$

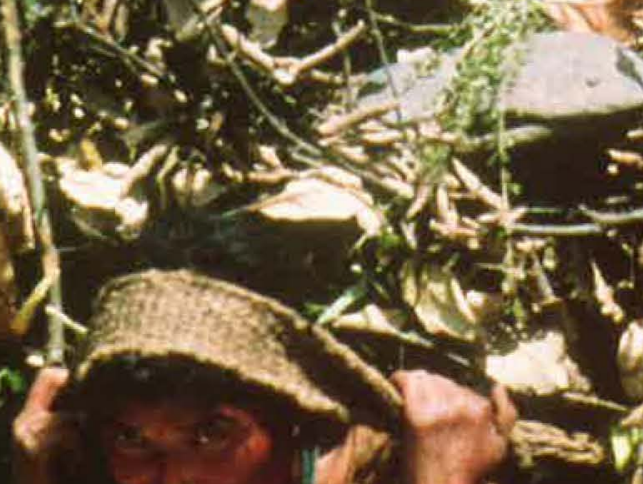

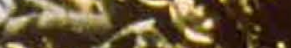

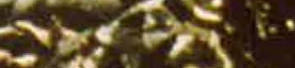

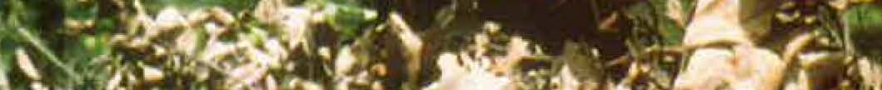

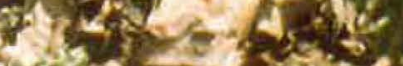

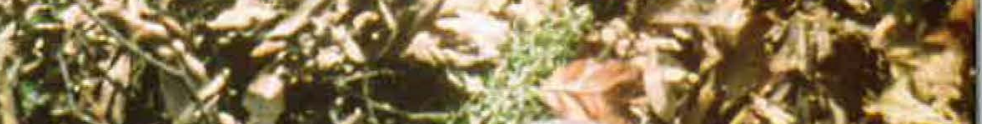

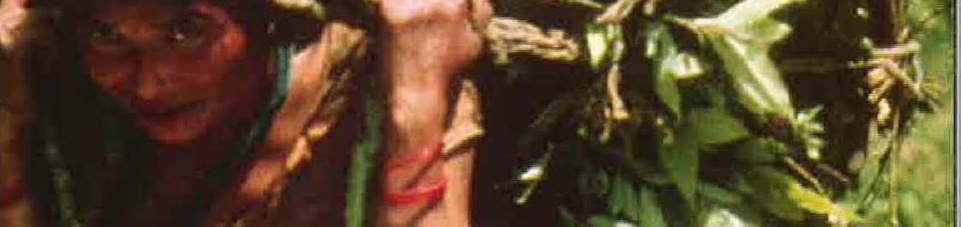


SEEDS is a pamphlet series developed to meet requests from all over the world for information about innovative and practical program ideas developed by and for low income women. The pamphlets are designed as a means to share information and spark new projects based on the positive experiences of women who are working to help themselves and other women improve their economic status. The projects described in this and other issues of SEEDS have been selected because they provide women with a cash income, involve women in decision-making as well as earning, are based on sound economic criteria, and are working successfully to overcome obstacles commonly encountered. The reports are not meant to be prescriptive, since every development effort will face somewhat different problems and resources. Rather, they have been written to describe the history of an idea and its implementation in the hope that the lessons learned can be useful in a variety of settings. They are also being written to bring to the attention of those in decision-making positions the fact that income generating projects for and by women are viable and have important roles to play in development.

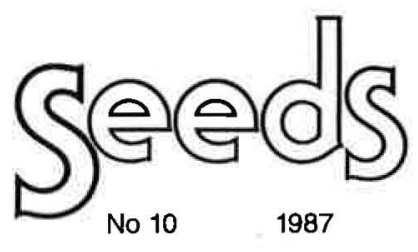

ISSN 073-6833
Administrative support and project direction for SEEDS is provided by The Population Council. Editorial policy is set by the SEEDS Steering Committee: Judith Bruce (The Population Council), Marty Chen (Harvard Institute for International Development), Cecilia Lotse (UNICEF), Katharine McKee (Center for Community SelfHelp), Jill Sheffield (Family Care International), Anne Walker (International Women's Tribune Center), Mildred Warner (The Ford Foundation), and Ann Leonard (Editor).

Publication of SEEDS is made possible by support of the Ford Foundation, Oxfam America, the Rockefeller Foundation, and the Population Council

Statements made and views expressed in this publication are solely the responsibility of the author and not of any organization providing support for SEEDS. 


\title{
Forest Conservation in Nepal: Encouraging Women's Participation
}

\author{
Story by Augusta Molnar
}

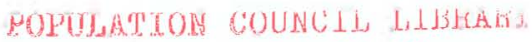 \\ J. Dag Hawuarkjojold Pla.za

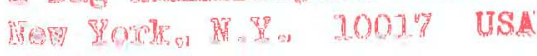

\section{Introduction}

For the hill woman of Nepal, the forest is the source of products vital to the household economy: firewood for cooking and heating and leaves for animal fodder and fertilizer. In addition to competing for these products with men and commercial interests, who utilize the trees for lumber, the situation has been made worse by the ever increasing pressure of population on limited land resources, which has resulted in increasing deforestation. The delicate ecological balance in the young and unstable Himalayan mountains has been upset, increasing the extent of erosion and the number of landslides. Deforestation is leading to increasing levels of silt in river beds, shifts in the course of rivers, and flooding in the southern plains. The impact of deforestation has profound effects on the lives of Nepali women. At the same time, women's roles as users and preservers of forest areas are crucial to the success of any program aimed at forest conservation.

This issue of SEEDS focuses on ways in which women have been involved in a government forest conservation and restoration program. As is common with many large-scale projects with a general impact, women were not a direct focus of the project's original design. As activities got underway, however, both the Nepali staff and their expatriate colleagues quickly realized that the direct involvement of women was crucial to the success of the project's participatory strategy. Over the initial five years, 1980 to 1985, a number of approaches to addressing women's needs and generating their active participation have been tried. 


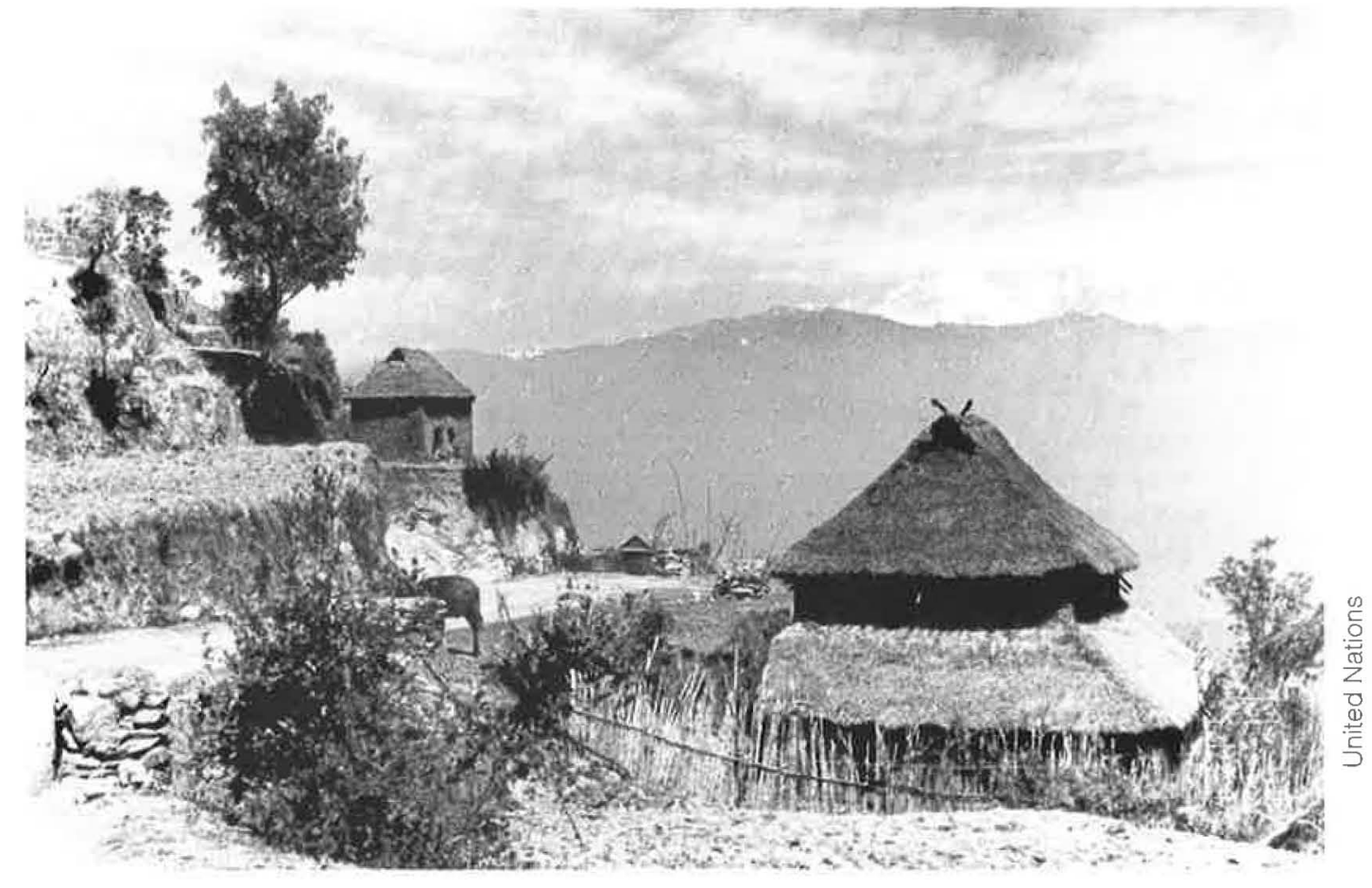

\section{The Importance of the Forest to Life in the Nepalese Hills}

With 96 percent of its population concentrated in rural areas, Nepal is one of the world's least developed countries. The majority of rural households depend for their livelihood upon a subsistence economy of agriculture and animal husbandry. The World Bank reported per capita income for the country as a whole at U.S. $\$ 140$ as of 1980 , although for much of the population the real figure is lower, sometimes not exceeding U.S. \$24 per year. The infant mortality rate is reported at 135 per 1000 live births and life expectancy is low (47 years for men and 46 years for women). Sixty percent of Nepal's population live in the hilly, mountainous section of the country south of the Himalayan range that spans the country from east to west. Here, in scattered villages, each household's subsistence strategies are intricately adapted to the varied and complex ecological conditions.

While the Nepali hill farmer is aware of the value of forest cover and the negative effects of widespread flooding and erosion, the immediate need for more agricultural land and forest products limits a household's ability to check deforestation through its own planning and resources. Nepali farmers have developed a sophisticated system of land preparation and terracing to limit land degradation, but this cannot resolve the problem of erosion on the marginal and steep slopes that increasingly have come under cultivation.

Deforestation also threatens the supply of forest products, particularly fuel. Eighty-seven percent of the country's energy consumption is in the form of fuelwood, and it is estimated that 95 percent of all wood taken from the forest is used for fuel. Fuel needs differ by community depending upon altitude, climate, and use of agricultural residue. Households in the lower hills, where cooking is the main use of fuel, have been estimated to consume $3,198 \mathrm{~kg}$. of wood per annum. In the colder, higher altitude areas, where room heating is necessary, the figure is much higher. ${ }^{(1)}$

At present there are no economically viable substitutes for the use of fuelwood for cooking purposes. In the southern plains, where fuelwood is more scarce, families burn cowdung mixed with agricul- 
tural residue, a common practice in India as well. Use of such a wood substitute in the hills, however, would be disastrous because of the importance of cowdung for the production of local fertilizers.

\section{Women's Roles in Forest Use}

Women's lives are the most seriously affected by environmental damage and the shortage of forest products. Women, together with their children, are the main collectors of fuel and other forest products such as animal fodder and leaf compost. They also take primary responsibility for herding family livestock, including cattle, sheep and goats. Women's roles in the collection of forest products must be seen in the context of their other household responsibilities.

While women are not as active in the cash economy as men (and are therefore underrepresented in the national statistics on participation in the labor force), recent studies employing data on family time-allocation have resulted in some realistic estimates of rural women's overall contribution to the household economy. In a study carried out in eight villages, women's total in-village work was found to be approximately 11 hours daily, as compared to approximately 8 hours for men. Looking at both wage earnings and household subsistence production, women contributed 50 percent to total household income with boys and girls contributing six percent and adult males 44 percent. ${ }^{(2)}$

Several factors explain the differential between male and female workloads. First, in addition to agricultural and animal husbandry responsibilities, women have primary responsibility for food processing, fuel and fodder collection, and domestic chores,

\footnotetext{
1. Thompson, M, \& Michael Warburton, "Uncerlainly on a Himalayan Scale," Mountain Research and Development, v.5, n 2, pp. $115-135$. Campbell, J,G, \& T.N. Bhattarai, "Preliminary Evaluation of Project Effects: Results of Key Indicator Surveys." Project Dooument. Kathmandu, Nepal: 1983, p. 25; and Campbell, J.G., "People and Forests in Hill Nepal," Project Paper No. 10. Kathmandu, Nepal: 1983,

2. Acharya, M. \& L. Bennett. "Women and the Subsistence Sector: Economic Participation and Household Decision Making in Nepal." Washington, D.C.: World Bank Working Paper No. 526, 1985.
}
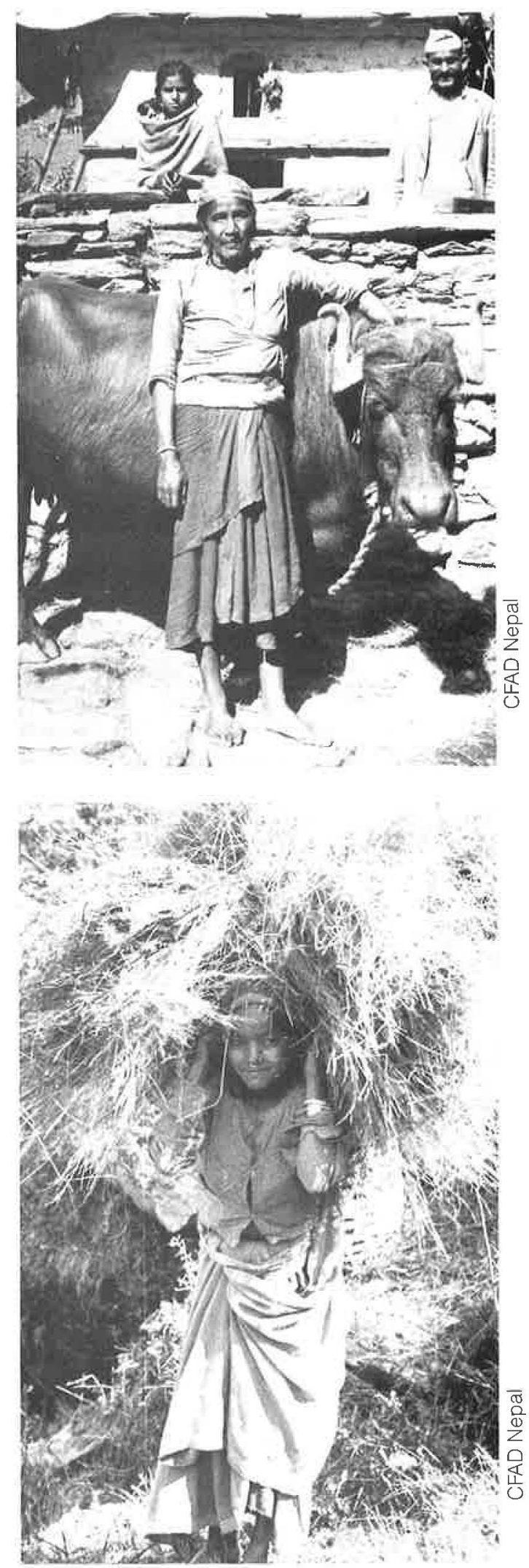


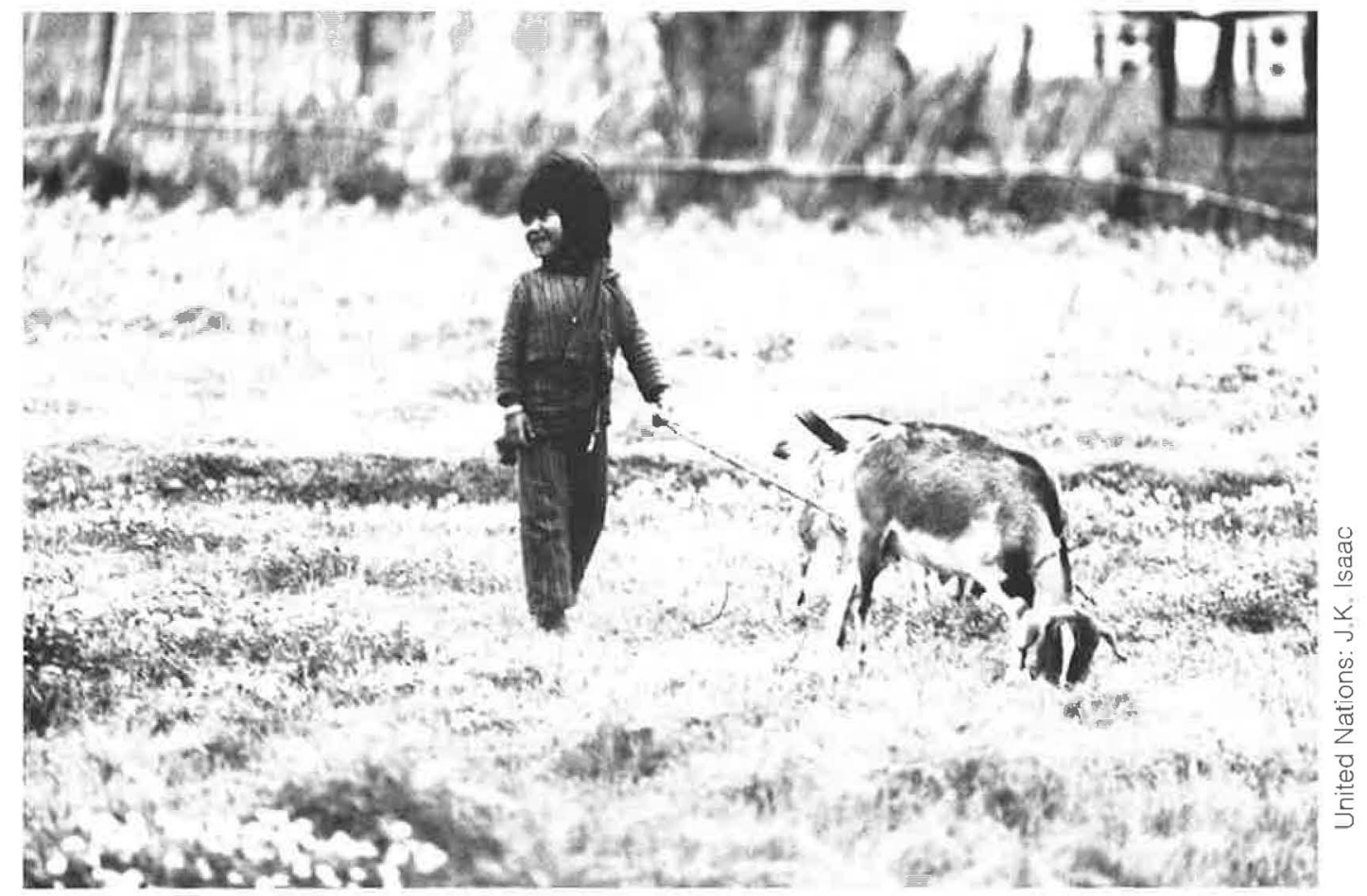

including cooking and child care. Second, in many households men have migrated to other parts of Nepal or to India in search of wage labor and temporary employment to supplement household income. The women then must assume a greater proportion of the agricultural tasks as well.

As forest products become scarce, the burden on the woman and her family becomes even greater. Krishna Devi, a hill woman of the Magar ethnic group, must spend a full day travelling to and from the forest to get fuel and fodder. When she was young, the forest adjoining her village provided plentiful supplies of wood and animal grazing land. Now the increasing animal and human population of the village has depleted the supply and she and her fellow villagers must now travel much further for these products.

By law we villagers are only allowed to collect whatever has fallen on the ground in the forest. The trees are used for timber for building for those lucky enough to be sold a permit by the forest officers. Women are left with the leaves, branches and twigs. Once, it wasn't too difficult to find wood on the ground. But now there is not even enough left over to fill one headload, unless you walk for miles and miles. And no fodder unless you cut the branches.

Even when I travel a long way into the forest, I still have to cut branches illegally to get a large enough headload to cook for my family. If l'm caught by a forest guard, he takes my cutting tool or tells me I have to pay a stiff fine. But what can I do? As it is now, I must bring my daughter with me to help collect fuel and fodder, so she often skips school to help me. I would rather that she got a good education so she would have a good chance in life. But I have no choice. There are too many other chores to complete. I now go to the forest every day that I have no work in the fields or grain to thresh or grind. And one headload (about 35 pounds) lasts only a few days. If fuel gets even more scarce, I will have to take my daughter out of school completely so she can help me with my other tasks.

The better woods are getting much scarcer. I must collect other species that burn very poorly. Sometimes a headload lasts hardly two days when it is made up of only soft wood and shrubbery. And the smoke that those woods create is awful. Some woods make my eyes burn and give the rice a bitter taste my husband can hardly stand. 


\section{The Project}

Between 1957 and 1977, as a result of the Nationalization Act of 1957, all forest land in Nepal had been considered to belong to the government, and was administered by forest department officers through the Ministry of Forests. Each local forest was under the jurisdiction of a forest guard attached to a district forest office and usage rights were strictly limited. Villagers could only collect fallen produce and had to apply to the district forest office for permits to cut timber for construction. After 20 years of government administration, however, the results of the Nationalization Act were mixed. So in 1977 the Government amended the Forest Act of 1957 by introducing two new pieces of legislation. One allowed for the legal transfer of tracts of degraded forest land to communities via the village administrative units, known as panchayats, ${ }^{(3)}$ for replanting and long-term maintenance. The other allowed for legal transfer of limited amounts of good forest land to the adjacent panchayats, to be protected and managed by the community in the manner most suitable for their own needs.

A new forestry scheme was designed on the basis of these legislative policies. It is being implemented primarily through a five-year project that tests comprehensive, community-oriented strategies for reforestation and resource utilization. The project began in 1980 and now operates in twentynine of the country's hill districts, drawing upon assistance and expertise from the World Bank, the U.N. Development Programme (UNDP) and the U.N. Food and Agricultural Organization (FAO). Its goals are to check deforestation, improve the forest cover, and increase the amount of fuel, fodder, timber and other forest products available for subsistence needs. It is very innovative in that it shifts responsibility for village forest resources from the government to the local villages. Its objectives include:

3. Panchayal is a South Asian term reterring to government by a small group of chosen village representatives, In Nepal, the panchayal is a unit of nine villages or "wards" adminislered by a group of 11 elected council members, one of whom serves as a council head, or Pradhan Panch.
1. Creation of a new forest division within the Forest Ministry, called the Community Forestry and Afforestation Division (CFAD);

2. Development of new forest officer training programs and new training facilities;

3. Transfer of forest lands to local communities in accordance with the new legislation:

4. Planting of degraded areas handed over to panchayats and creation of community management plans for all forest land reverting to community control;

5. Establishment of community nurseries to raise seedlings for private and community tree planting;

6. Research on locally-viable fuel, fodder, timber and multipurpose species, particularly fast-growing species; and

7. Dissemination of improved, woodburning cookstoves.

These various project objectives involve many support activities. District forest offices now have trained forest extension workers (CFAs) to work with local communities. Nurseries have been started and are staffed by villagers, who are selected by the community and trained by the project. Since the project is the first to make use of the new forest legislation, it has had to work out the management, administrative and legal details affecting land transfer. Extension materials have been developed for all aspects of the project. In particular, considerable extension work has been necessary among communities to make villagers aware that the planned activities and new legislation are designed for their benefit.

(Many villagers fear that the Government may change its mind once again and nationalize the new plantations. There is also frequent distrust of the panchayat leaders, particularly in communities that are made up of several distinct villages of varied ethnicity, all administered by a single panchayat body. A single panchayat may contain a variety of Hindu caste groups and one or more distinct ethnic groups of Mongolian origin. While the panchayat is the 
most convenient administrative level at which to establish community-based activities, its leadership does not always represent the interests of the entire community.)

Resistance has also been strong in the Forest Ministry itself, where traditional forest department staff fear "losing control" over "their" forests and thereby losing their prestige. Orientation courses for all foresters, therefore, are an important support activity aimed at convincing these officers of the value of community management and helping them assume new roles as technical advisors and management consultants, rather than policemen and village adversaries.

\section{Women and the Forestry Project}

The project design document did not make specific reference to women or specify particular strategies to involve women in planned activities, apart from the inclusion of an improved, woodburning stove program. The planners considered that since activities were directed to general household needs, the project would therefore benefit both sexes equally. Once the project began, however, the staff quickly recognized that successful implementation would require actively involving women, as well as men. Two factors would make it difficult to encourage such involvement, however: women's traditional position in Nepalese society and the absence of female staff in the Forest Department at the time the project began.

While Nepalese society is not as restrictive as in some parts of South Asia, women traditionally are not active in public or political affairs (although participation varies greatly among Nepal's numerous ethnic groups). In general, women do not attend panchayat council or village meetings and their movements in the village are confined to those required by domestic and agricultural duties and to visiting female friends and relatives. They do not spend much time in public places, such as the ubiquitous tea shops where men typically hold many informal discussions. While women go to market towns and areas on shopping excursions, they do not converse with strange men except for business purposes, nor do they stay in the market longer than required. This is particularly true for younger women, both married and unmarried.

Yet it quickly became apparent that women are as involved, if not more involved, in the use of the forests than men, and that women's active participation was necessary in many activities, such as planting. When degraded forests are replanted, they must be closed to animal and human intervention for the first few years while the seedlings become established. Since women generally graze the animals, they must be committed to and involved in protection of these plantations. If they do not understand or accept the replanting, they may feel that it has taken away irreplacable grazing land and will oppose the closure. Also, since closure of local forest areas requires women to change their livestock feeding practices from grazing to stall feeding, which requires them to spend hours each day cutting grass, they may allow their animals to enter the closed areas. Therefore, the project has devoted considerable time to extension work with women to gain their support.

Forest department staff were initially quite surprised to find that men were ill-informed as to the exact amount of fuel and fodder required by village households and its local availability in the surrounding forests. "Ask my wife," was a common reply to such questions, which were usually directed by a male extension worker to the male head of the household.

Men and women also have preferences for different species of trees. As Krishna Devi's testimony makes clear, women seek types of wood with specific qualities for burning, not just those that grow quickly and easily adapt to local soil and climate conditions. Men and women differ in their emphasis on end products too: men are more often concerned with timber production; women with fuel and fodder. The particular mix of fuel, fodder and timber producing trees, and the amount that should be cut over a single season to meet house- 


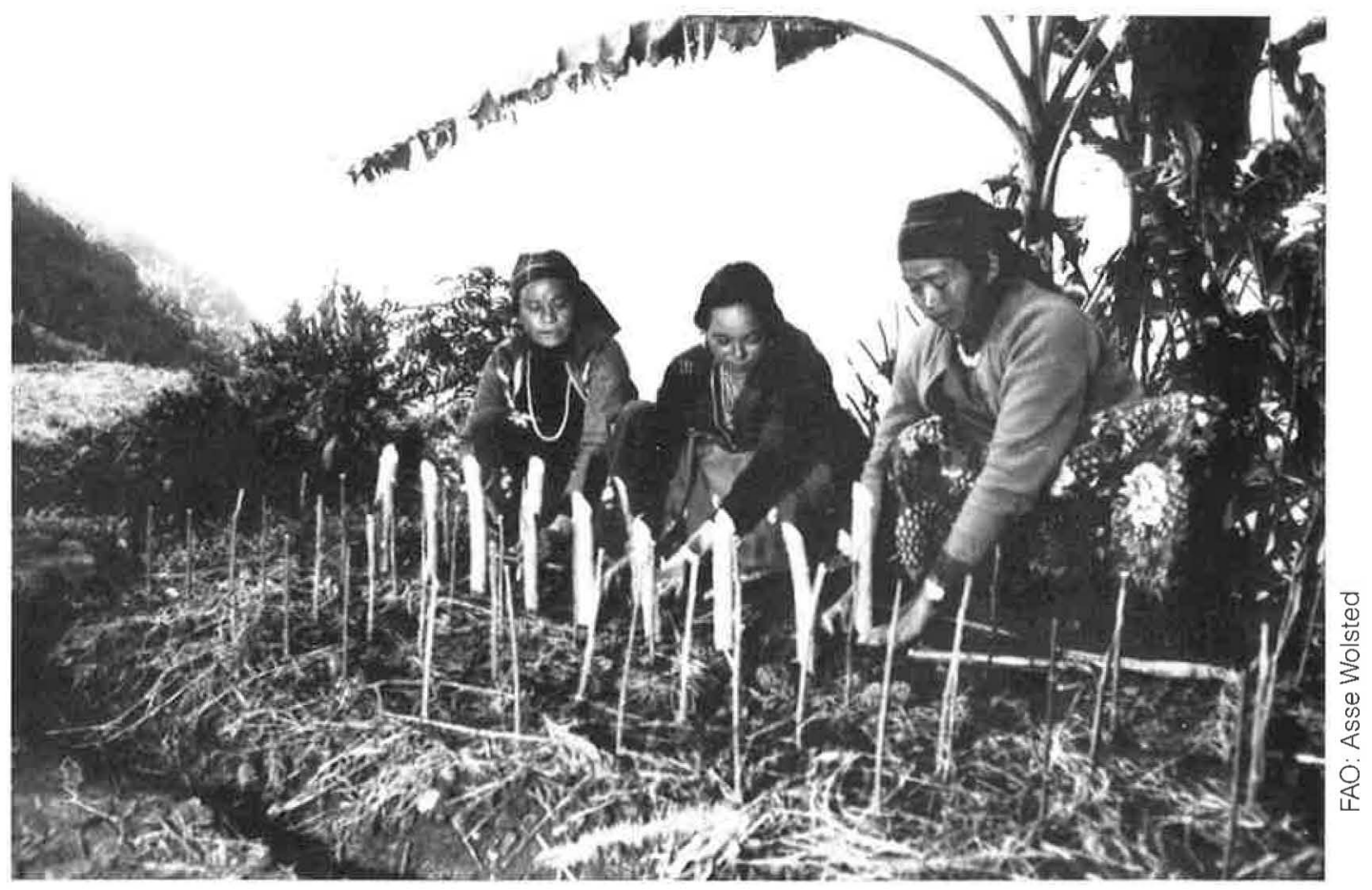

hold needs, are issues that men and women treat very differently. Therefore, it is only logical that women be consulted in drawing up workable forest management plans, since if the plan does not provide for adequate fuel and fodder, inevitably they will break its rules.

\section{Involving Women}

From the project's experience, women can be reached through a forestry project in three basic ways:

1. Analyzing women's needs and roles, ideally at the design stage, and then as the program is implemented, in order to ensure that women can benefit;

\section{Targeting extension information to women; and}

3. Directly involving women as project staff, village workers, and decision-makers.

So far, the project has been stronger in tackling the first two strategies. Had women been a specific focus in the design phase of the project, it is likely that more progress would have been made in fielding female staff from the beginning. The areas in which women have been a strong focus are development and dissemination of extension and training materials and systematic data collection on the progress and problems experienced by field staff in extending women's participation. In addition, women have been actively involved in the stove program and, recently, have been emerging as staff workers and active members of community forestry committees.

The difficulties faced in reaching women also have been compounded by the complexity and broad coverage of the overall project and its innovativeness, both in terms of activites and the build-up of administrative support. Orientation of forest department staff and creation of the monitoring and evaluation units, research units, and so forth, have all been time-consuming and problematic and have detracted attention from getting women involved. 


\section{Male Forest Extension Workers and Village Women}

Forest extension workers, known as CFAs, are attached to each district office, and have been recruited for the project and trained in a two-year program in the southern Terai forestry school. Most of the recruits have been drawn from the Terai area itself only recently have hill people become aware that these positions are open. To date, all CFAs have been men, since there are no facilities at the Terai school for female students. The project has built a forestry school in the hills, at the town of Pokhara, with facilities for women, but the school has not yet produced any graduates.

The CFAs have found it difficult to reach village women with extension advice. There are many reasons for this. First, they have been slow to develop effective extension skills because the department had no prior experience in this area and extension materials have only recently been developed. Secondly, those CFAs from the Terai region come from a cultural tradition that restricts women's behavior much more than is the case among the hill populations. Not surprisingly, these CFAs tended to avoid women in the villages where they were posted.

Ram Kumar is a male CFA who has worked for the project since its start and who comes from the Terai.

When I was first posted to the hills with the project, I never talked to village women because that sort of behavior would have angered village men in my home district. Women were also hard to find; they never attend group discussions with men and are usually busy with household work. We employed women as nursery workers to plant seedlings, but I oversaw their work rather than giving them extension advice. I also had my hands full when I first arrived. The information we were given in training was not always applicable to the planting and nursery problems I actually found in the villages. Some patches were so eroded that it was a miracle if even the hardiest pine species grew. Local farmers also knew more than I did sometimes, and I was afraid they would laugh at my advice. I had enough trouble without trying to talk to women.

I never realized how important women were for the project until I was transferred to another district with a really exceptional district officer. He made me realize that the women provided a different perspective on species preferences and forest usage. We also lost many seedlings in private homesteads because only men came to the nurseries. They planted the trees at home, but since their wives never knew they had been planted, the trees were trampled by cattle or children.

When we organized forest committees in participating villages to select village staff, allocate land for planting or protection, and decide on forest management strategies, we were to told to be sure at least one woman was elected on the committee. But the women selected seldom said anything in committee meetings. And I had no idea who the influential or dynamic women were in the village so / could suggest that a different woman join the committee. Supervising planting, allocation of forest land, running the nurseries and planning project activities take most of my time anyway. I oversee four villages, and they are each about a three hour's hard walk. It is hard for me to do enough extension work with the men, must less the women. Maybe if there were some special courses for us during the two-year training, I could have done a better job.

\section{Women's Involvement in Training and Extension}

Training programs for project staff and village-level workers (both almost exclusively male) and development of extension materials and their use by local communities have offered ways to involve village women and raise the awareness of women's importance in forestry efforts. All levels of field staff receive training - the forestry extension workers who are attached to the district offices and cover up to five panchayats apiece (CFAs), locally-recruited nursery 


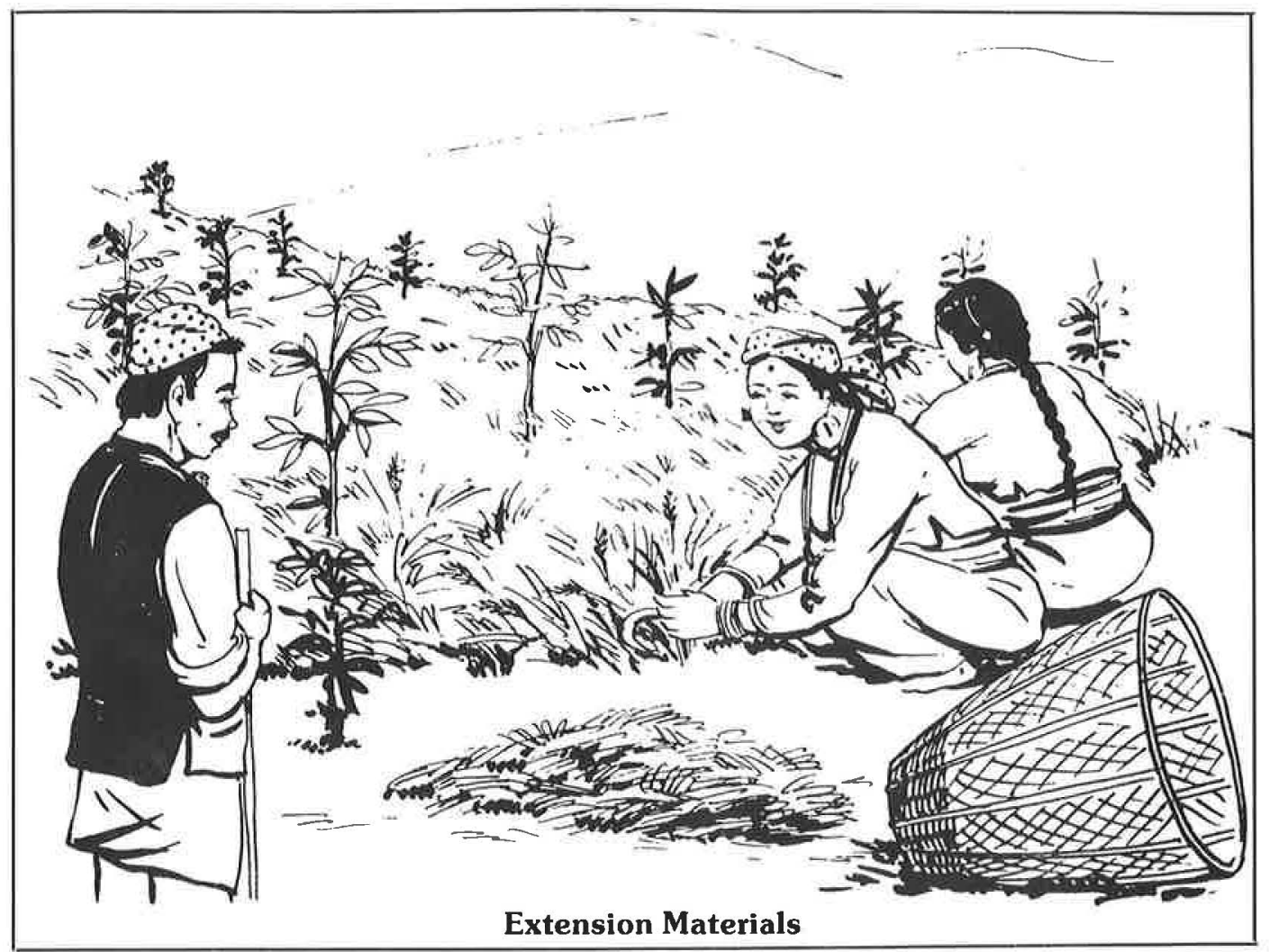

foremen, female stove promoters, male stove installers, and locally-recruited forest watchers, who protect the legally transferred forest lands. The forestry extension workers provide village-level training.

Extension efforts have included use of pamphlets about the legal rights of communities to newly planted and newly transferred forest areas, posters, slide shows and leaflets about project activities (including the qualities of various species of trees, planting techniques, stall-feeding, etc.). The extension materials-developed by the project in cooperation with the Thailand-based Development Training and Communication Project (DTCP), an agency specializing in grassroots communication-discuss women's central role in forestry. All materials use simple Nepali language and numerous pictures, including depictions of women planting trees and engaging in other forestry operations.

Slide shows and films shown at village presentations have been particularly successful. If scheduled in the evenings, when women are free from their chores and can attend, these are popular and effective. One slide show, "The Buffalo Must Eat Everyday," uses a female villager as the main character to discuss the importance of stall-feeding. The documentary film on Nepal's environmental crisis, The Fragile Mountain ${ }^{(4)}$, has been translated into Nepali for these showings. It is ideal for extension work with village women because it allows them to talk about how they perceive the problems and solutions. In these showings, the women will chat with one another while the commentator speaks, but are always silent when a villager is being interviewed in the film. There is also a regularly broadcast radio program that includes sessions devoted to women's participation in the project.

4. A Sandra Nichols film shown as part of the NOVA series on US. public television. (See Appendices for further information,) 


\section{Women as Forestry Staff}

The main employment of women under the project has been as nursery labor, filling seedling containers, watering seed beds and planting. This work neither increases women's participation in decisionmaking nor increases the awareness of other village women about project activities. To date only five of the 240 nursery supervisors have been women. In two cases these women took over after the death of a male relative, demonstrating that village men do not shun the employment of women. But their presence has not had the desired impact in reaching other women nor has it led more women to visit the nursery. In fact, some staff have complained that these women are less effective than men because they are more shy when discussing the project with men while not being active in seeking out village women. In part, this may be a problem of their accidental selection as opposed to being specifically selected and appropriately trained for the position. A few women have been employed effectively as forest watchers: village workers hired to watch over new plantations and to educate villagers who violate the closure rules about the advantages of the project. This is a position that should increasingly be filled by women, particularly as it is women who most frequently go to the forest for fuel and fodder.

A number of expatriate foresters have been employed by the project, recruited under country volunteer programs (Peace Corps, British VSOs, Japanese volunteers and from an FAO program of Associate Experts), to assist at the district headquarters and to work with local CFAs and villagers. Some of these foresters are women, and they have had a positive role in identifying some of the problems and constraints in reaching women, suggesting ways to increase women's involvement, and providing a strong role model to villagers and staff by demonstrating the value of trained women in forestry. Because they are foreigners, these women are able to move freely in the field with little criticism from villagers about the suitability of their role.
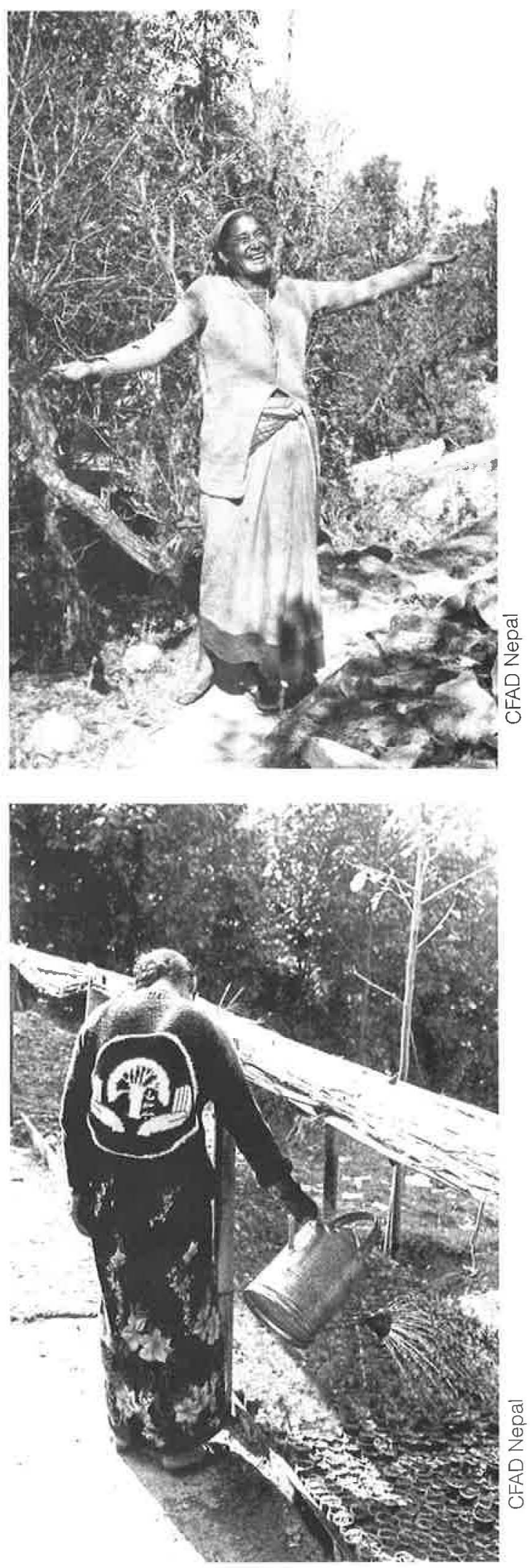
The recruitment of women as CFAs is an important issue for the project, particularly as plans call for extension of the project into a second five-year phase. Some women are presently enrolled in a course in Natural Renewable Resources at the university in Pokhara. Although some of these women could be recruited as CFAs until some women graduate from the new forestry school, simply recruiting women as CFAs alone will not address all the problems of women and extension work. Female CFAs may not be as effective as males in working with men in the panchayats, given the present social status of women, nor would the presence of a female CFA carrying out the identical set of duties now required of male CFAs necessarily guarantee that more extension work reaches women. Indeed, one serious complaint of present CFAs is that their job requires so much travel in order to oversee several villages, that they have little time left to talk to individual farmers.

The project must find a solution which utilizes women effectively as extension workers. If the experience with women's programs in Nepal and elsewhere is indicative, this will require special tailoring of training, job descriptions, supervision and support systems. For example, the women will need help to establish initial contacts in their client villages. It has been learned from family planning services that when lone women are required to travel and to stay overnight in strange households, they may be the subject of rude gossip. CFAs who al ready have contacts with individual women in all of the villages where they intend to work, and have respectable places to stay, are more easily accepted by the local society.

\section{Experience with Women as Decision-Makers}

Women leaders have begun to emerge as the project's activities have expanded to more villages. Initially some emerged spontaneously, but there was no formal means to incorporate them into the project. One example of a women acting on her own in- itiative involves a woman resident of Ilam panchayat in eastern Nepal, who became interested in forestry after attending an election meeting held by a female candidate to the General Assembly. During the meeting, attended by women from a number of government-supported women's organizations, some time was devoted to explaining the new forestry program. This woman was so enthusiastic about what she heard that she began making visits to different households in town explaining the advantages of private tree planting and encouraging families to take seedlings from the nursery. Since her activities coincided with the onset of the planting season, the district forest officer hired her for a few months with funds from his budget for daily laborers. He then tried to incorporate her more formally into the project at the end of the season, but there was no opening for a nursery foreman or forest watcher, the only two paid positions in the project budget, and there was no separate fund from which to pay her.

Another similarly motivated member of a local women's organization came forward in a far western district, Dandeldhura. She approached both the district office and project staff to request support for carrying out extension work with women in the area. Again, local staff were unable to hire her, given the inflexibility of the budget categories for local workers. She had no desire to tend a nursery - the only position open-but wanted to concentrate on extension work. She still hopes to get support in the form of extension materials and help from local staff in organizing meetings with women about private planting. She is particularly concerned by lack of female participation in this program and believes more intensive extension work that clearly specifies the benefits of the program to women (along with better coordination of the stocking of the nursery with multipurpose fuel/fodder/fruit species) could greatly increase the number of women taking seedlings.

Thus far, no formal means have been found to incorporate such women into project activities. Since the project is intended to provide a replicable model for forestry 


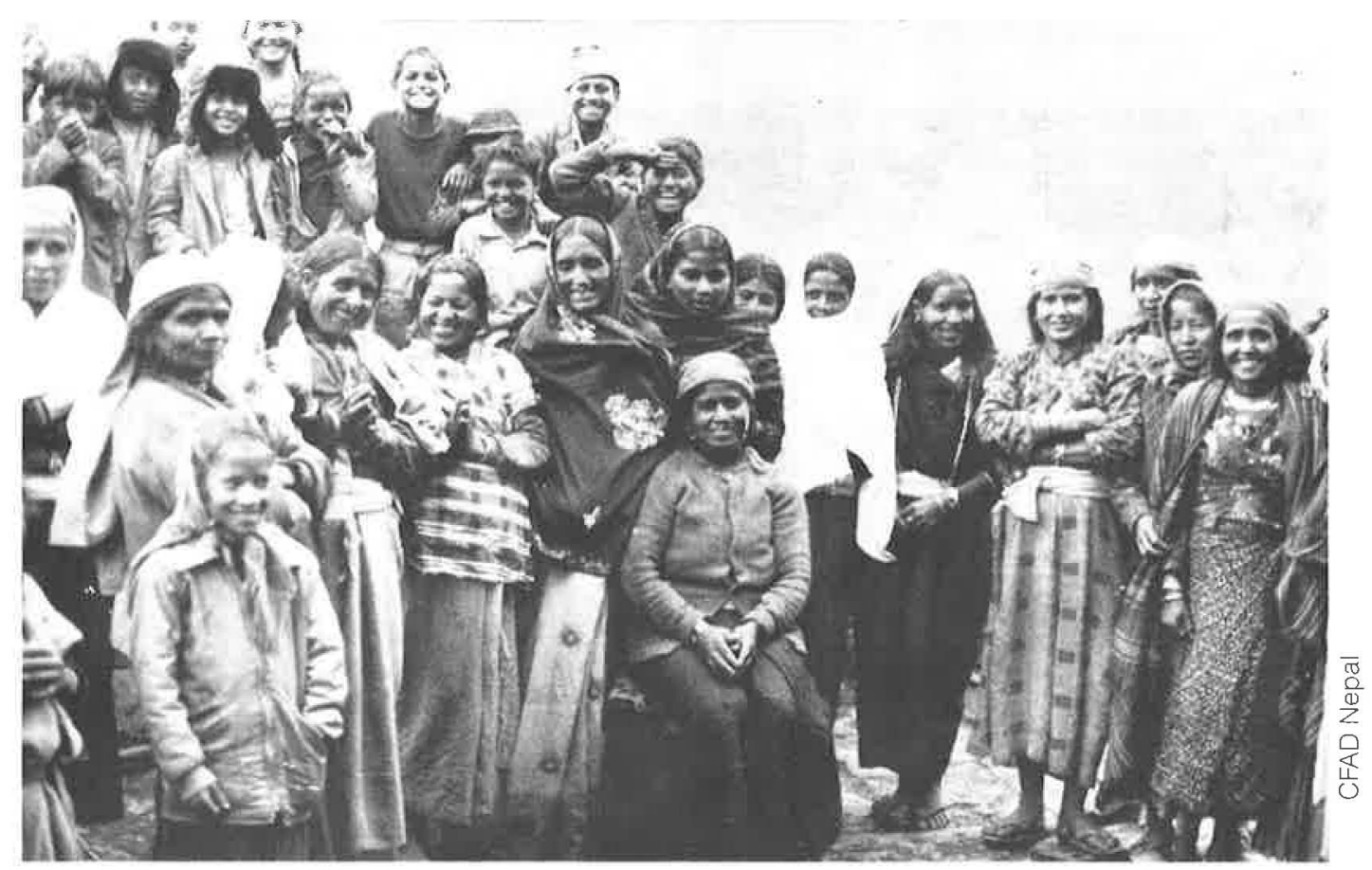

development throughout Nepal, central staff do not feel that arbitrarily creating a single post for such "exceptional women" presents a viable solution. What is needed is a mechanism for routinely employing such women, or at least covering their experises. One possible mechanism is the project initiated village forest committees. In two instances, women have formed such committees on their own. In Kaski district in central Nepal, where many villagers traditionally have maintained forest lands as a sub-unit of the panchayat, the project successfully sought modification of forest legislation allowing sub-units to take control of forest management rather than the larger, less homogeneous panchayat. Their committee is formed on this sub-unit level and was organized by a bright, assertive woman who had just graduated from high school and was training to be a teacher. She decided that community forestry had great relevance to village needs and felt a female forest committee could be an effective vehicle for needed social action.

Another committee is made up of 11 members. Its original organizer has been appointed treasurer and the president is the wife of a village leader. The women chose the leader's wife as committee head because she is middle-aged, experienced and, by virtue of her position in the community, has access to important insider information about local political affairs. The committee already has overseen the planting of 3500 seedlings in one degraded area of their village and has instituted a policy of charging a minimal fee for permits to use existing sections of forest. This fee provides revenue for future planting efforts and other planned community improvements, such as piped water and new school facilities.

An interesting aspect of the two committees is that both were started completely at the instigation of local village women, although they have since received encouragement from district staff. Furthermore, the committees are highly regarded by the men in the village--and the men are happy to abide by their decisions regarding village forest resources. Participation by women in decision-making regarding management of village-controlled forests is certainly a crucial step in the direction of long-term community forestry. 


\section{The Fuel Saving Smokeless Cookstove}

Women have been serving successfully as extension workers in the stove component of the project. Almost all Nepali families cook on wood-burning cookstoves. Kerosene and bottled gas are limited to urban areas due to high cost and poor supply. Many women and children suffer from respiratory infections and eye problems caused by exposure to the smoke from these traditional cookstoves. Recent studies estimate that the smoke pollution inside a Nepali house produces as much of one harmful hydrocarbon as would be produced by smoking 20 packs of cigarettes a day!!

To combat health problems and, at the same time, improve the fuel efficiency of cookstoves, the forestry division collaborated with a Nepali research institute and several international appropriate technology groups to develop a series of prototype stoves that were similar to the ones that have traditionally been used in Nepal. From these, one model

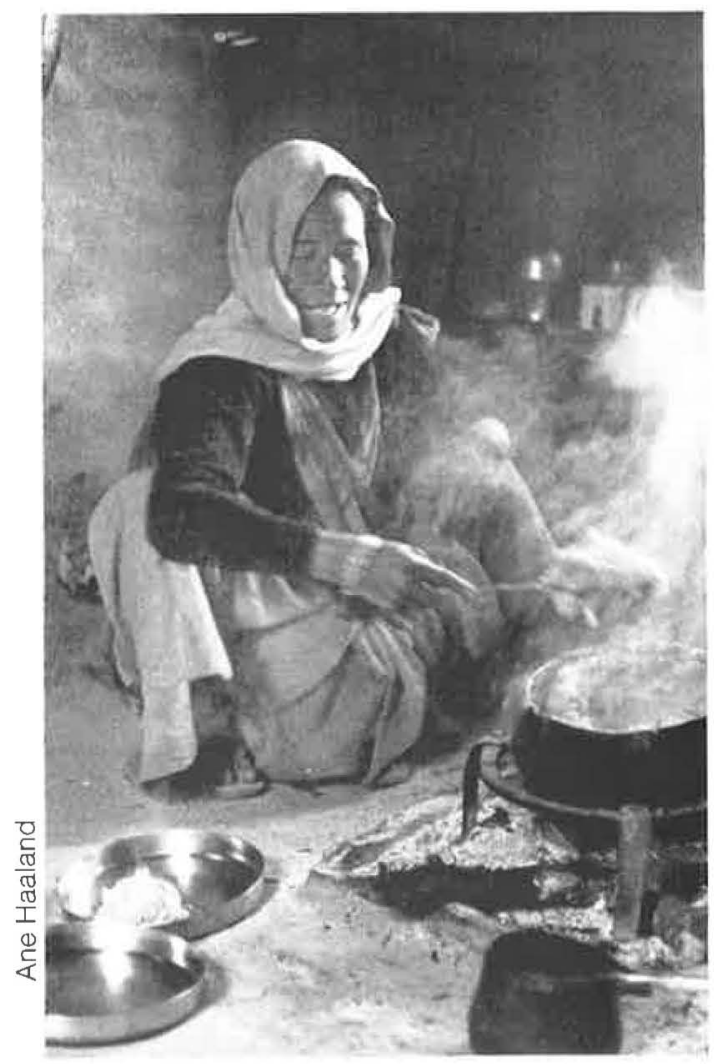

was selected that had two prefabricated ceramic bowls and a prefabricated ceramic chimney that could be installed in a traditional mud stove housing.

The model was fuel-efficient because the prefrabricated pieces ensured that the inside of the stove was in correct proportions, and it was low-cost because the ceramic pieces could be made locally by traditional Nepalese potters after they received training from the project. Since it used the traditional mud housing, members of traditional Hindu castes could use the stove because they could build their own structure around it: they would have rejected a stove constructed by members of an "unacceptable" caste if it came directly in contact with their food. In addition, the stove has no dampers to regulate air flow (as do many improved South Asian cookstoves), thereby avoiding the need to teach women how to use the dampers properly.

The plan was to install an initial 15,000 stoves on a promotional basis, in the hopes that families would then be willing to pay for replacements as the stoves wore out. The initial distribution also served as a test of stove reception, manufacture, supply, and logistics, and provided guidance towards future marketing strategies.

To disseminate the stoves, nine female stove promoters and 24 male stove installers were hired, with plans to expand these numbers to 30 and 60 , respectively, as the areas covered by stove construction increased. Stoves were initially introduced in the Kathmandu valley where the first potters were trained and follow-up was easiest. Other hill districts have since been added and the Kathmandu potters have trained the potters in these new districts.

The first stove promoters were young home economists. They were given training both in stove promotion and in community forestry, so they could tell women about forestry activities as well as fuel conservation. One woman of the Newar ethnic group from Kathmandu, Chandra Devi, has been a very successful and enthusiastic stove promoter. 


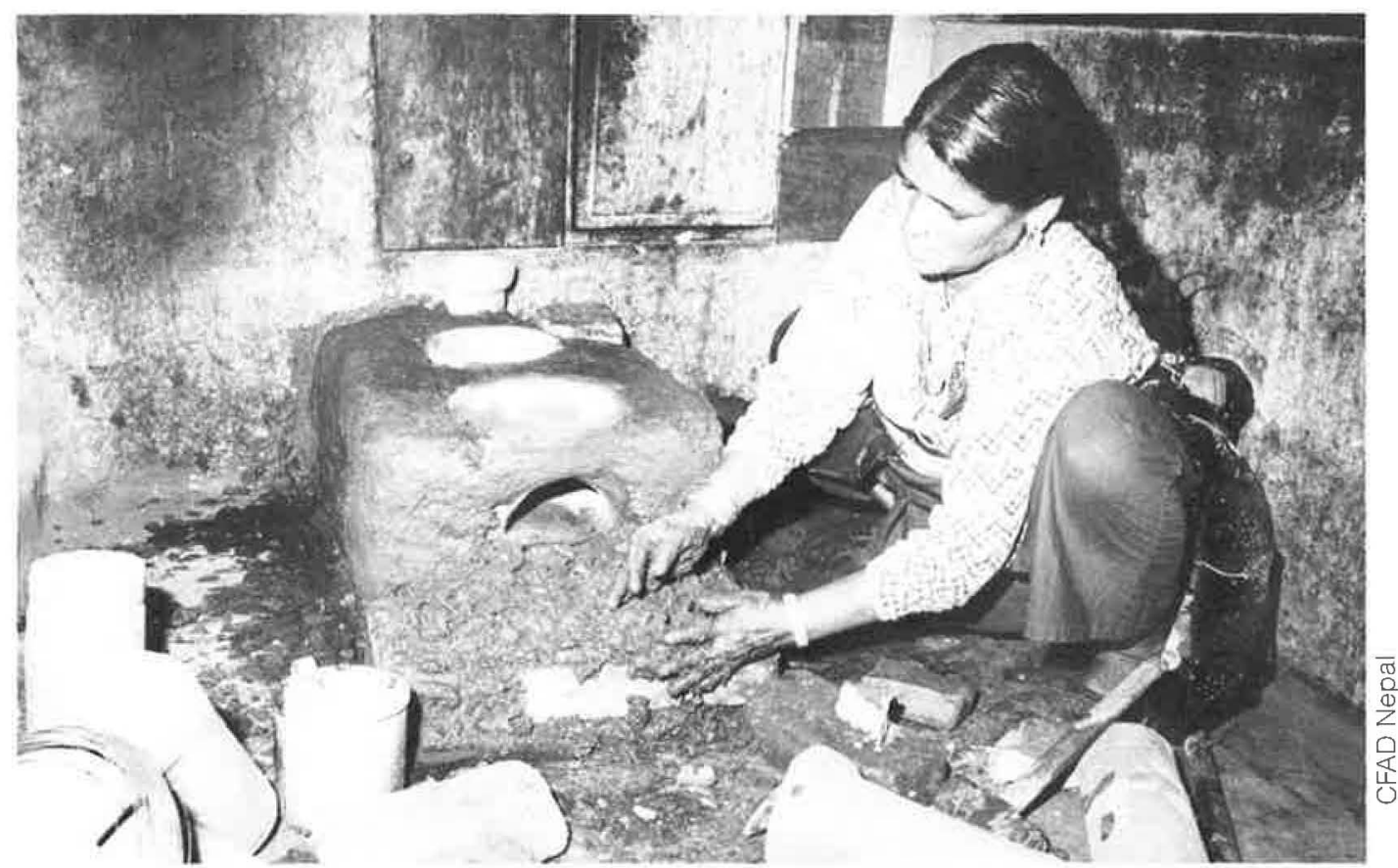

At first it was difficult to get women interested in new stoves. They were very reluctant to try them. One thing that did interest them, however, was the chimney. Nepali households are really uncomfortable to sit in when a woman is cooking.

The response to the stoves has been really positive. Of course, we have had a lot of problems, but many have been resolved. And the women are willing to work with us to find solutions. Some of the earlier stoves did not have enough clay in the mud housing and the housing cracked between the two stove pieces after only a few months. The designers did more tests and we changed the mud mixture. The worst problem was with the chimney. The installers often had to put the chimney closer to the outside wall than specified so that it wouldn't break. But then the wind forced the smoke back into the room. Several families were so keen on keeping the stove that they rigged up a kerosene can on top of the chimney to keep the wind away. We still have to find a more permanent solution to this problem.

There are less people in the original sample now than during the first year due to breakage and other problems, but many women use the new stove exclusively. Our follow-up visits have made a big difference. For one, we never would have noticed a lot

of the problems, and many women had problems adjusting to the new stoves. My visits gave them a chance to ask questions. Sometimes they were upset that the stoves don't create as hot a fire on the front burner, so I show them different ways of cooking the various dishes in a meal so that the new stove will actually be faster. And I can be sure they know how to clean out the chimney regularly. I also talk to them about the planting program. Quite a few stove users have gotten trees from the nursery as a result of my visits.

So far the model stove seems to be a good one for saving fuel. A study of families using the stoves found an average wood savings of 28 percent, with a 40 percent savings reported in one region. However, breakage and other problems have led to a drop-off in stove acceptance. Initial feedback obtained in 1983 showed that 70 percent of all stoves installed were in use; one year later the rate had dropped to 60 percent.

Now that the stoves are being distributed in more hill areas outside of Kathmandu, continued research and development is increasingly important. Since the 
stoves are still being distributed free, it is not known whether families will eventually be willing to purchase them. Initially the largest market will be in urban areas where firewood must be purchased (the project estimates that a viable stove can save 500 $800 \mathrm{~kg}$. of fuel per year and can pay for itself in three months in an urban area). In rural areas users may not see the savings as readily but, where women must travel long distances to collect fuel, the stove should also prove a popular purchase, though initially in smaller numbers.

\section{Future Directions}

The project is attempting to develop the infrastructure for carrying out a program of community forestry that will benefit all Nepalis, including women. To date activities of particular value to women have been training and development of extension materials, the management plan system enabling the community to plan how their local resources will be used, development of an improved cookstove program, and collection of information and experiences on the problems and possible future approaches to involving women actively as both staff and decisionmakers.

If women are to become as actively involved in the project as men, project staff must continue to monitor activities in this regard and to explore how to:

- more directly involve women at various levels and better orient male project staff in skills required to reach women;

-increase involvement of women in forest committees; and

- find means to incorporate village women enthusiastic about forestry into the project.

These are important challenges that could have a far-reaching effect by making women a more integral part of the project.

In terms of the cookstove component of the project, when the stoves are distributed on a wider scale, it will be necessary to consider such issues as quality control of commericially produced stove pieces, and maintenance of an adequate local supply. The biggest issue currently facing the stove program is how long it should be overseen by the Forest Department. Many foresters feel it falls outside their area of expertise and think the stove unit should be relocated or disbanded once stoves are sold rather than given away. Others feel that fuel conservation is as important to forestry as tree planting and that no other government agency will show as much interest in such a program.

\section{Lessons Learned}

1. The key to involvement of women in a forestry project is an awareness of the central roles that women play in forest utilization and maintenance. Ideally this should be reflected in the initial design of the program. Staff must continually monitor the project to be certain that planned activities are meeting women's needs.

\section{Extension efforts should be tailored} specifically to women and their interests. This can be done by using media that women can understand, whether literate or not, and by scheduling presentations at times when women can attend. Materials directed to men also should explain the importance of women's involvement in the project.

\section{Women will support a project when} they can see tangible results. Since it takes a long time for trees to mature, early positive results such as increased grass production or village nurseries stocked with tree species of known value for farm planting will help elicit women's support.

4. Women need to be involved in decision-making regarding community forestry management plans if these plans are to be effective. Aspects requiring their involvement include: types of species to be grown, desired forest products, how much produce to distribute, when and to whom, methods of harvesting, and revitalization of protected forest areas. 
5. While project staff are aware of the value of more direct involvement of women, they have also recognized the complexity of the problem of women's participation, particularly in a broad sector project like community forestry. Successful experiences involving women in other sectors elsewhere in Nepal and South Asia have mainly been implemented on a small scale within a limited geographic area, and have depended upon intensive local planning and strong support and supervision by female staff. Simply creating a cadre of female workers to undertake extension work with women is not enough. Sufficient staff support and resources to identify suitable recruits and supervise their activities are also necessary.

6. Employing female forestry staff will increase the involvement of women and better address their particular needs. However, unless women's and men's duties are tailored to meet these objectives, women's needs may still be overlooked, even if a large proportion of staff are female.

7. The fielding of female extension staff requires overcoming specific obstacles to their recruitment, posting and supervision. The problems female extension staff will face within a particular cultural setting need to be specifically addressed when designing their duties, in the recruiting of candidates, in helping them establish themselves within client villages, and backing them up with adequate supervision.

8. Since an important component in controlling environmental destruction is conservation, project planners need to look closely into how resources are used. Since so much wood is used by women for cooking purposes, development of an improved cookstove program represents a positive effort in fuel conservation that com- plements preservation and resoration of forest lands. In addition, the stove component provides project staff with an important entree for reaching women that can be used for discussion of broader environmental concerns.

9. A mass stove distribution program will only succeed if attention is paid to developing a long-term, self-supporting program. A stove program should not be grafted on to a forestry project with the expectation that forestry staff, busy concentrating on other activities, will automatically have the expertise or the time to devote to such a program. Provision to hire additional staff, or to train and redefine assignments of existing staff, must be made prior to launching a program in the field.

10. Female extension workers have proved to be an integral part of an improved stove distribution program. In Nepal, women have been helpful in training women to use the new stoves properly, in gathering information about women's attitudes towards the stoves, and in informing women about other aspects of wood conservation.

11. The stove program has been very successful in large part due to emphasis on long-term research and development of models that eventually can be disseminated through the private sector. Experiences of improved cookstove programs around the world increasingly stress the importance of (a) developing a product with the end users' needs in mind; (b) testing acceptability and cost effectiveness in a real life setting; (c) carrying out long-term research and follow-up to resolve problems in design and durability; (d) teaching women to modify their cooking and fuel preparation habits to make optimal use of new stoves; and $(e)$ establishing the commercial marketability of the stoves within the local economy. 


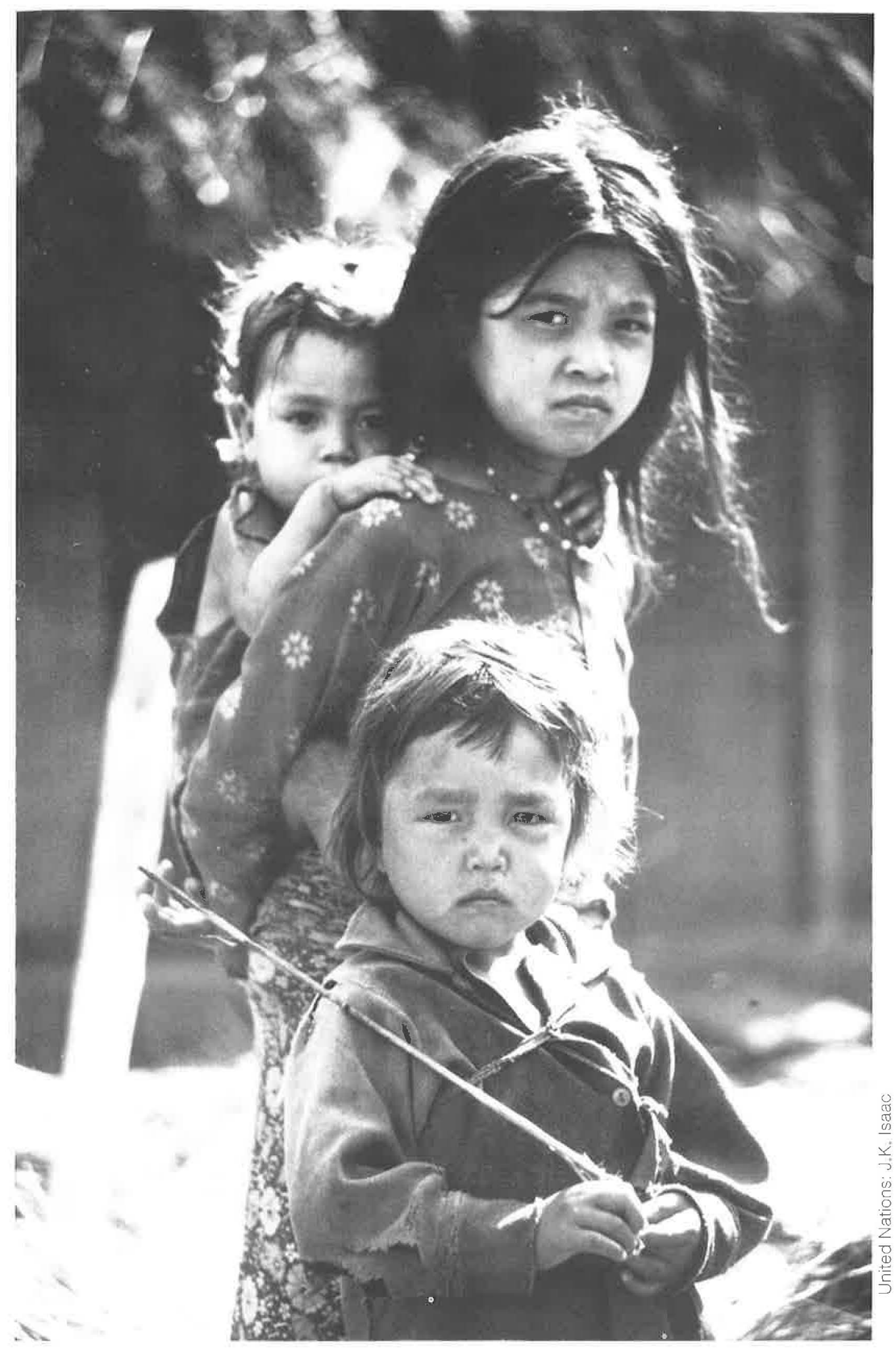




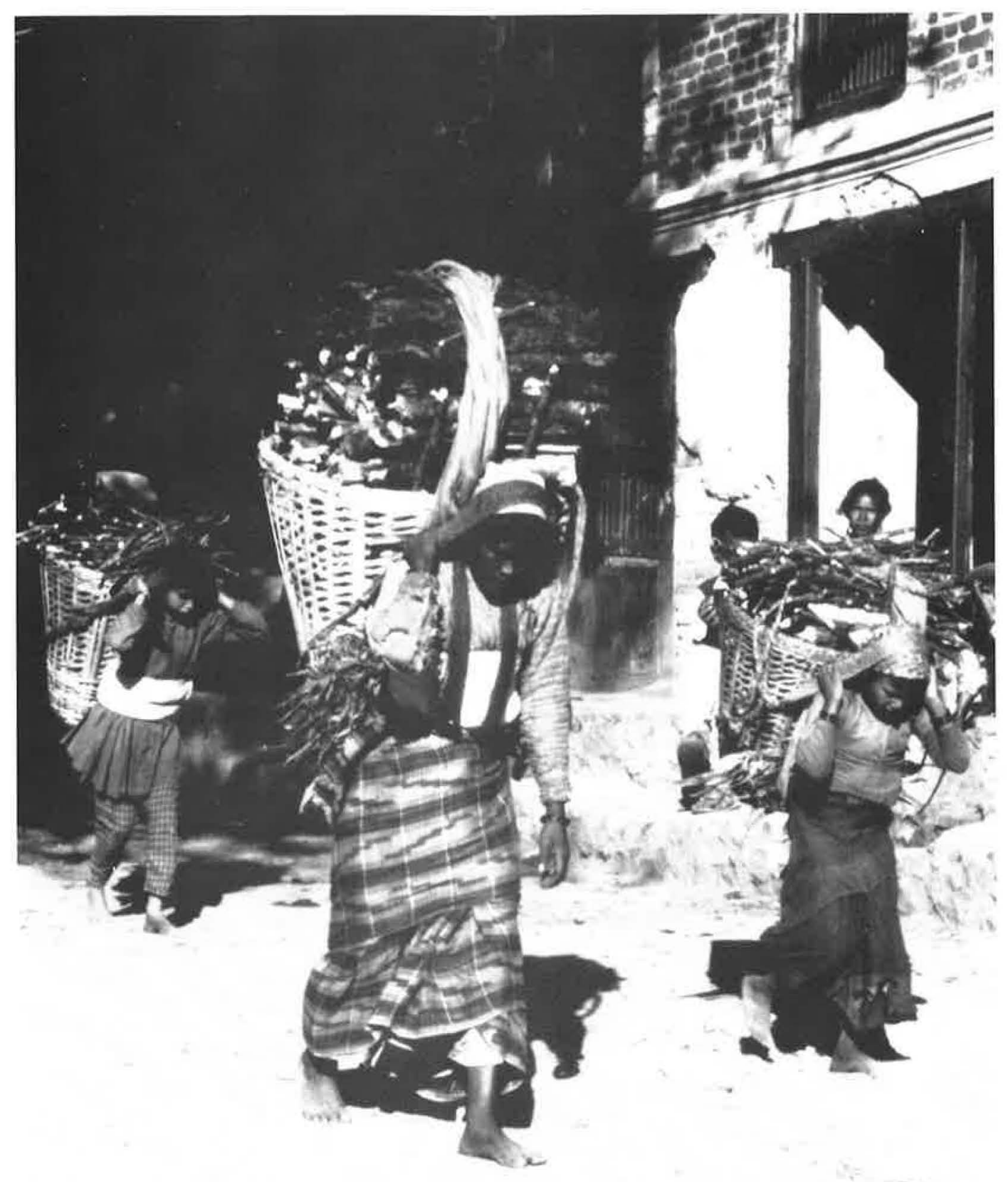

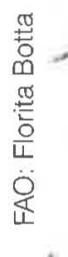




\section{Appendix I}

The following is a summary of the involvement of women in a forestry project in an African setting.

\section{The CARE Agroforestry Project, Siaya District, Kenya by Hilary Feldstein}

This project was begun by CARE/ Kenya in 1983, funded through CARE/ Canada by the Canadian International Development Agency. Technical assistance has been provided by the International Center for Research in Agroforestry (ICRAF).

Siaya District in Western Kenya was chosen as a pilot district because of its acute fuelwood problem. A primary objective was to ensure a sustainable fuelwood supply with fast-growing, multi-purpose trees. The project built upon earlier projects in Kenya which had demonstrated: the importance of off-farm resources to poor families, including access to trees on privately held lands; the importance of predominantly women's groups in undertaking community activities, extending new technologies, and as sources of information; and the differences between men's and women's access to and use of trees and their products.

Two important decisions were made early on: to work with already organized groups, rather than organizing special nursery groups, and to train equal numbers of men and women field level extension personnel. Field officers and extension workers are trained to do an initial consultation or diagnosis with groups to determine current practices and preferences as to species, uses and other tree characteristics before planning nurseries or recommending specific agroforestry techniques. The program takes particular care to seek out the opinions and knowledge of women through such means as asking questions on topics on which they have specialized knowledge, calling specifically on women and talking with women as a group or individually in situations separate from men.

Groups are selected which have an adequate local site, sufficient water supply and motivation to provide voluntary labor for the nursery. Nurseries are begun during the short rains in December. The project provides the polybags, seeds and tools necessary; labor is provided by the group members. By the long rains in March, seedlings are of sufficient size to be planted outside. Extension workers then make agroforestry plans with individual farm households (men and women) to determine what material should be used for various farm needswindbreaks, fodder, mulch, fuelwood, etc. The project also works with primary schools where emphasis is on fruit trees for use at school and for cuttings which can be taken home by the children to be planted for home production.

Between 1983 and 1985, the project grew from an initial eight groups to 225 women's groups and 75 primary schools. Approximately one million trees have been planted. By 1987, the project had received requests from 500 community groups wanting to participate.

The key to this high level of community interest has been the participatory approach used to determine what is needed, the individual and careful attention given by CARE field workers from establishment of a nursery to planting and monitoring, and the equal attention given to the needs of women and men. As a result of this open and collaborative approach, attention has been redirected to learning more about indigenous species and encouraging their propagation, emphasizing multiple uses for wood besides fuelwood and timber, and recommending planting according to individual farm needs rather than a static model.

For more information contact: Ms. Louise Buck, CARE/Kenya, P.O. Box 43864, Nairobi, Kenya. 


\section{Appendix II}

The following are some selected references in the area of women's participation in forestry projects.

\section{Publications}

Agarwal, Anil and Sunita Narain. "Women and Natural Resources." New Delhi: Centre for Science and Environment, 1985.

Agarwal, Bina. "Under the Cooking Pot: The Political Economy of the Domestic Fuel Crisis in Rural South Asia." Sussex, U.K.: Institute of Development Studies, IDS Bulletin, v. 18, n.l, 1987.

Foley, Gerald and Patricia Moss. Improved Cooking Stoves in Developing Countries. London \& Washington, D.C.: Earthscan, Technical Report No. 2, 1985.

Hoskins, Marilyn. Women in Forestry for Local Community Development: A Programming Guide. Washington, D.C.: U.S. Agency for International Development.

Hoskins, Marilyn. Rural Women, Forest Outputs and Forestry Projects. Rome, Italy: FAO Forestry for Local Community Development Programme, 1986.

"Forests, Trees and People," Forestry Topics Report No. 2. Rome: FAO, Via delle Terme di Caracalla, 00100 Rome, Italy. (Also available in Arabic, French and Spanish)

Intermediate Technology Consultants, Ltd. and FAO. Guidelines for the Monitoring of Pilot Stove Development Schemes. Rome, Italy: FAO, August, 1985.

Scott, Gloria. "Forestry Projects: How Women Can Help-and Help Themselves." Appropriate Technology, v. 9, n. 3, December, 1982. (IT Publications Ltd., 9 King Street, London WC2E 8HN, UK)
"Workshop on 'Women's Participation in Forest Management'", Final Recommendations. Kathmandu, Nepal: Human Resources Development Division, Winrock International, April, 1987.

\section{Film}

Nichols, Sandra. The Fragile Mountain. (Available in $16 \mathrm{~mm}$. film in English and Nepali; video cassettes in Beta or VHS. For purchase information contact: Sandra Nichols Productions, Ltd., 6420 Goldleaf Drive, Bethesda, MD 20817. For rental information: Sandra Nichols Film Library, P.O. Box 315, Franklin Lakes, NJ 07417.)

\section{Project Information}

Information about this project and the community forestry experience can be obtained from:

The Community Forestry and Afforestation Division, Ministry of Forests, Kathmandu, Nepal. (Various project papers are available.)

Food and Agriculture Organization of the United Nations (FAO), Via delle Terme di Caracalla, Rome 00100, Italy.

World Bank. South Asia Projects Division. 1818 "H" Street, N.W., Washington, D.C. 20433. 
Design: Ann Leonard

Typography: Village Type and Graphics

Cover Photo: United Nations: J.K. Isaac

Printing: Graphic Impressions, Inc.

HQ

1870.9 Molnar, Augusta

.\$43 Forest conservation in

no.10 Nepal

POPULATION COUNCIL LIBRARY

NEW YORK

We invite your comments and your ideas for projects which might be included in future editons of SEEDS. If you would like additional copies of this issue or would like to be included on the SEEDS mailing list, please write to:

Ann Leonard, Editor

SEEDS

P.O. Box 3923

Grand Central Station

New York, New York 10163 U.S.A. 


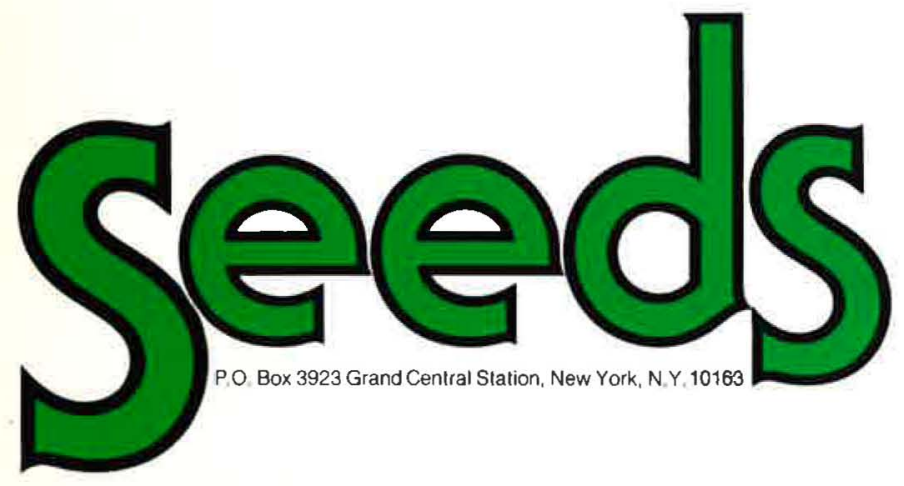

